\title{
Biocontrol of economically important weed species through endophytic fungi isolated from Parthenium hysterophorus (Family: Asteraceae)
}

Yaseen Ahmad', Muhammad Nauman Ahmad', Afia Zia', Syed Sartaj Alam², Raja Asad Ali Khan ${ }^{3}$ and Muhammad Riaz ${ }^{4}$

\begin{abstract}
Background: Fungal endophytes produce a variety of secondary metabolites which can be explored for herbicidal activities. Parthenium is a very aggressive and fast-spreading weed in Pakistan. The endophytes of Parthenium made it superior over other weeds. Those endophytes can be isolated, identified, and incorporated in sustainable agriculture to biologically control other severe weeds.

Main body: The present study was conducted to isolate and identify the endophytic fungi from the roots of Parthenium hysterophorus (Family: Asteraceae) and evaluate their cultural filtrate against the growth of three selected weed species, i.e., Chenopodium album, Avena fatua, and Convolvulus arvensis. Moreover, pot experiments were conducted to evaluate the effects of cultural filtrates of these endophytic fungi against the germination, growth, and other physiological parameters (cellular contents, respiration, and cellular leakage) of the abovementioned three weed species. Three endophytic fungi, i.e., Alternaria, Aspergillus, and Drechslera spp., were isolated from the roots of $P$. hysterophorus. Among these endophytic fungi, cultural (hyphal) filtrate of Alternaria spp. exhibited the strongest phytotoxic effect, followed by Drechslera spp. and Aspergillus spp. against the selected weeds. Moreover, all the three endophytic fungi showed significant reduction in the germination as well as other physiological parameters of the weed species.

Conclusion: It is concluded that the utilization of endophytic fungi could be a non-chemical, effective, ecofriendly, and low-cost biological control method that can be used for the biomanagement of fast-spreading and aggressive weeds.
\end{abstract}

Keywords: Fungal endophytes, Parthenium hysterophorus, Cultural filtrates, Weed control

\section{Background}

Weeds are undesirable plants because they not only reduce productivity, but also affect human's health by causing allergies and skin diseases. Moreover, weeds have always been one of the most serious problems for agriculture and environment due to their competitive nature for nutrients, water, and light with agricultural

\footnotetext{
* Correspondence: ssalam@aup.edu.pk

${ }^{2}$ Department of Plant Pathology, The University of Agriculture Peshawar, Peshawar, Pakistan

Full list of author information is available at the end of the article
}

crops and forest plants as well as the hazard they possess to animals (Cimmino et al. 2015a). Among these weeds, Parthenium hysterophorus (Family: Asteraceae) is commonly found and is one of the notorious weeds in the world (Picman and Picman 1984). Various management strategies, including chemical, cultural, mechanical, and biological, have been used against weeds around the world (Melander et al. 2017; Korres 2018). Most of the strategies are very effective in weed management at small scale; however, at a large scale, they are not costeffective (Zimdahl 2018). On the other hand, use of

\section{Springer Open}

(c) The Author(s). 2020 Open Access This article is licensed under a Creative Commons Attribution 4.0 International License, which permits use, sharing, adaptation, distribution and reproduction in any medium or format, as long as you give appropriate credit to the original author(s) and the source, provide a link to the Creative Commons licence, and indicate if changes were made. The images or other third party material in this article are included in the article's Creative Commons licence, unless indicated otherwise in a credit line to the material. If material is not included in the article's Creative Commons licence and your intended use is not permitted by statutory regulation or exceeds the permitted use, you will need to obtain permission directly from the copyright holder. To view a copy of this licence, visit http://creativecommons.org/licenses/by/4.0/. 
chemical pesticides has been the most cost-effective method, which has led to a large-scale use of chemical pesticides differing widely in respect to toxicology, unit activity, spectrum, and environmental effects (Yadav and Devi 2017). Therefore, there is a need to develop crop protection strategies that do not rely on genetic modification and/or harmful chemicals (Kanchiswamy et al. 2015). Nowadays, there is an increasing trend for the development of alternate sustainable, environmentally friendly integrated weed management strategies, based on natural bioherbicides. For the past few decades, hostspecific fungi, bacteria, and viruses have been utilized for this purpose (Harding and Raizada 2015).

Among microbial communities within the plants, the fungal community and especially endophytic fungi play a dramatic role in the physiology of their host weed plants and also produce and/or induce plants to produce phytotoxic compounds or other metabolites that have activity against other weeds, insects, and fungal pathogens (Khan et al. 2020a; Khan et al. 2020b). Hence, the main sources for the discovery of novel biologically active compounds are from endophytes. Endophytes are involved in defensive mutualism and habitat adapted to symbiosis with host plant which helps host plant to cope with biotic and abiotic stresses (Rashid et al. 2016).

In the present study, Parthenium employs its root microbiome as a tool to engineer its soil ecosystem to make it less favorable to plant competitors. To confirm these hypotheses, this study was aimed to isolate and identify the endophytic fungi and the evaluation of their herbicidal potential for the management of some selected weeds.

\section{Materials and methods}

\section{Collection and preparation of plant material}

Healthy roots of $P$. hysterophorus were collected from Malakandir farms of the University of Agriculture Peshawar, Pakistan. Roots were kept in polythene bags and transferred to the laboratory for further processing. Healthy roots were again sorted and thoroughly rinsed with sterile distilled water to remove dirt and debris. Following rinsing, surface sterilization was carried out with $70 \%$ ethanol $(\mathrm{v} / \mathrm{v})$ for 1 min and $0.1 \%$ mercuric chloride (v/v) for $5 \mathrm{~min}$, respectively. The roots were again thoroughly rinsed for five times, using sterilized distilled water to remove the excess of chemicals from the surface of roots. The roots were spread on sterilized tissue paper to dry for $30 \mathrm{~min}$ under sterilized conditions (laminar flow unit). The dried and sterilized roots were then used for the isolation of endophytic fungi (Priyadharsini and Muthukumar 2017).

\section{Isolation and identification of endophytic fungi}

The sterilized roots were then cut into pieces of $1 \mathrm{~cm}$, then plated on to Sabouraud dextrose agar (SDA). The $\mathrm{pH}$ of SDA was adjusted in the range of 7.5-7.8. The inoculated plates were then incubated at $28^{\circ} \mathrm{C}$ for $1-2$ weeks to allow the growth of endophytic fungi. Pure cultures of endophytic fungi were obtained by transferring hyphal tips from the growing colonies to fresh SDA plates (Hamzah et al. 2018).

Identification of endophytic fungi was done on the bases of the morphological and cultural characteristics. Hyphae of the endophytic fungi were placed on slides, stained with lactophenol cotton blue, and observed under compound microscope. Cultural and microscopic characteristics were noted, and identification was done based on available keys (Gilman 2001).

\section{Preparation of fungal filtrates}

Flasks having potato dextrose broth (PDB) media were individually inoculated with $5-\mathrm{mm}$ agar discs of each of the 3 endophytic fungi grown in a Petri dish. Inoculated flasks were incubated at $27^{\circ} \mathrm{C}$ in an incubator for 15 days. After 15 days of incubation, fungal cultures from each flask were first filtered through Whatman filter paper no. 1 and then passed the filtrate through $0.22-\mu \mathrm{m}$ filter papers with the help of vacuum filtration to remove any hyphae or spores present in the filtrate. Fungal cultural filtrates were preserved at $4{ }^{\circ} \mathrm{C}$ for further use.

\section{Laboratory bioassay}

In vitro studies were carried out to evaluate the bioherbicidal effects of cultural filtrates of the isolated endophytic fungi on the germination and early seedling growth of 3 weed species, namely Chenopodium album, Avena fatua, and Convolvulus arvensis. Seeds of these weed species were obtained from the Department of Weed Science, University of Agriculture Peshawar, Pakistan. Seeds were surface sterilized with $70 \%$ ethanol for $3 \mathrm{~min}$, followed by $1 \%$ sodium hypochlorite $(\mathrm{v} / \mathrm{v})$ for $5 \mathrm{~min}$. Seeds were then rinsed with sterilized distilled water for five times. Each weed species had 4 treatments and 3 replicates. A total of 36 Petri dishes ( $90 \mathrm{~mm}$ diameter) were used, each having 15 seeds on 2 layers of sterilized filter paper. Five milliliters of each cultural filtrate was added to each Petri dish. PDB was used as a negative control. The experimental design was completely randomized design (CRD), and each treatment was repeated 4 times. Petri dishes were placed in a growth chamber with alternating temperatures of $10 /$ $20{ }^{\circ} \mathrm{C}$ in the 8/16-h dark/light regime (Alshallash 2018). Data regarding percentage of germination, shoot length $(\mathrm{mm})$, root length $(\mathrm{mm})$, and plant biomass $(\mathrm{mg})$ were recorded after 15 days.

\section{Foliar spray pot experiment}

Another experiment was conducted to evaluate the cultural filtrates of endophytic fungi on 2-week-old weed plants under controlled conditions. Pot experiments were carried out in a horticultural nursery of the 
University of Agriculture Peshawar during the month of October to November 2019. Eight seeds of each weed species were sown per $60-\mathrm{cm}$-diameter perforated plastic pot each having $2.5 \mathrm{~kg}$ soil, i.e., sand, clay, silt $=30.31 \%$, 26.22\%, 43.93\%; pH 6.8 and EC of $0.288 \mathrm{dSm}^{-1}$. Two weeks after emergence, pots were thinned to 4 healthy and equal-sized plants. Three-week-old plants were sprayed with fungal cultural filtrates $(100 \%)$ at the rate of $100 \mathrm{ml}$ per meter square area. Treated weed plants were examined for percentage of cellular respiratory activity, percentage of electrolyte leakage, chlorophyll content $\left(\mathrm{mg} / \mathrm{cm}^{2}\right)$, shoot length $(\mathrm{cm})$, and biomass $(\mathrm{g})$ on 1 and 7 days of the spray.

\section{Estimation of chlorophyll content}

Chlorophyll content of leaves was measured with the help of atLEAF chlorophyll meter. Chlorophyll meter was properly calibrated by following the manufacturer's guidelines. Each leaf SPAD value obtained was the average of 6 readings. The values were then converted to milligrams per square centimeter of chlorophyll content (Novichonok et al. 2016).

\section{Determination of cellular respiration}

Cellular respiration is an indirect estimation of tissue viability, which is determined by using 2,3,5-triphenyl tetrazolium chloride (TTC). Viable cells reduced TTC to red-colored triphenyl formazan by accepting electrons from mitochondrial electron transport chain. The reduction in cellular respiration is the indication of tissue damage from fungal cultural filtrate. To estimate root oxidizability, $50 \mathrm{mg}$ of tissue was treated with $5 \mathrm{ml}$ of $0.4 \% \mathrm{TTC} \mathrm{w} / \mathrm{c}$ and $5 \mathrm{ml}$ of $0.06 \mathrm{M}$ phosphate buffer. The mixture was then incubated at $40{ }^{\circ} \mathrm{C}$ for $2.5 \mathrm{~h}$, followed by $2 \mathrm{ml}$ of $2.0 \mathrm{~N} \mathrm{H}_{2} \mathrm{SO}_{4}$. After incubation, the root was ground in $10 \mathrm{ml}$ of absolute ethanol and absorbance was measured at $485 \mathrm{~nm}$. The triphenyl formazan content was expressed as a percentage of the control, calculated according to the following equation.
The formazan content calculation was termed as cellular respiration.

$\%$ Cellular respiration inhibition $=($ Absorption of thawed tissue) $/($ Absorption of control) $\times 100$

\section{Relative electrolyte leakage}

Relative electrolyte leakage (REL) of selected weed plants was measured, following the protocol of Kaur et al. (2010). A 200-mg leaf tissue was incubated in pure sterilized distilled water for $2 \mathrm{~h}$ at $25^{\circ} \mathrm{C}$ in a test tube, and electrical conductivity (EC) was measured. The test tube containing leaf material was boiled for $30 \mathrm{~min}$, and the conductivity was measured (E2) again. The relative electrolyte leakage (\%) was calculated, using the formula: $\operatorname{REL}(\%)=\mathrm{E} 1 / \mathrm{E} 2 \times 100$.

\section{Statistical analysis}

The experimental design used in the present study was CRD. Each treatment was repeated 3 times. The data obtained was subjected to one-way ANOVA. Least significant difference (LSD) at $p<0.05$ was carried out to compare the mean of treatments. For statistical analysis, software package Statistix 10.1 was used.

\section{Results and discussion}

Cultural and microscopic characteristics of fungal isolates Three endophytic fungi were isolated from the roots of $P$. hysterophorus. The colony color and microscopic description of the endophytic fungi are shown in Table 1 and Fig. 1. Hyphae of all the isolated fungi were septated; however, there were variations in morphology of conidiophores, conidia, and colony color. The conidia of Drechslera spp. were of 3-5 cells and cylindrical in shape. Similarly, the conidia of Alternaria spp. were ovoid having elongated apical structure. Moreover, chains of conidia were observed on the conidiophores of Aspergillus spp. as shown in Table 1. Every plant species has its own microbiome containing a range of microbes including endophytic fungi. Various fungal species have

Table 1 Cultural and microscopic characteristics of endophytic fungi from Parthenium hysterophorus

\begin{tabular}{llll}
\hline Features & Fungal genus & & Drechslera spp. \\
\cline { 2 - 4 } $\begin{array}{lll}\text { Colony description } \\
\text { Surface color }\end{array}$ & Aspergillus spp. & Alternaria spp. & Brown-gray \\
Reverse & Plue-green & Olive brown & Black \\
Texture & Velvety & Brown-black & Fibrous \\
Microscopic description & & Velvety & Septate and brown \\
Hyphae & Septate & Dark & Brown 4.5-6 $\mu$ wm wide \\
Conidiophores & Smooth walled & Large & Light brown, 3-5 celled \\
Conidia & $2.5-3.5 \mu m$ in diameter & Ovoid with an elongated & and cylindrical \\
\hline
\end{tabular}



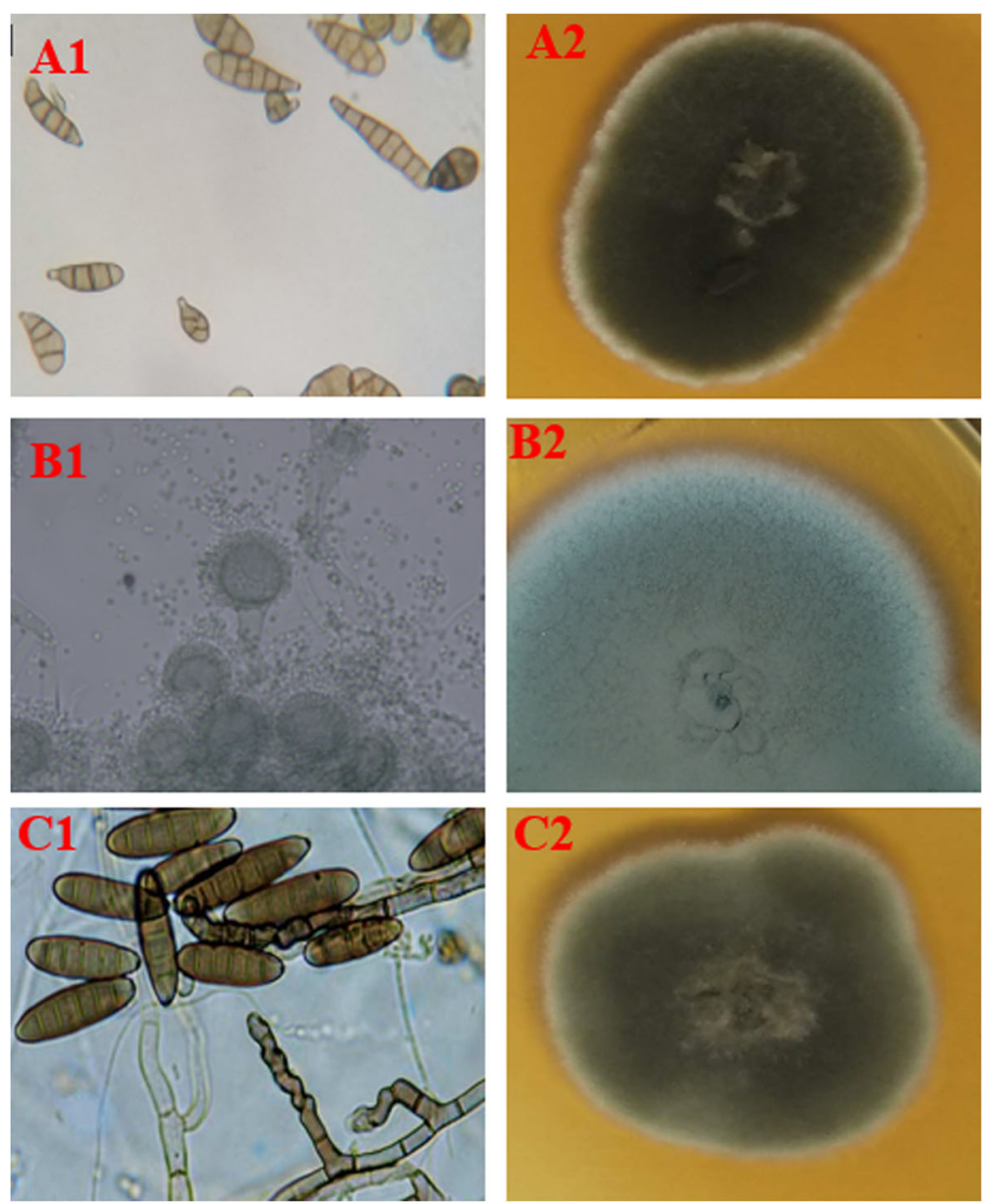

Fig. 1 Microscopic (1) and fungal colony characterization (2) of endophytic fungi isolated from P. hysterophorus. (A) Alternaria spp., (B) Aspergillus spp., (C) Drechslera spp

been isolated already from $P$. hysterophorus. Obtained results of the endophytic fungi from $P$. hysterophorus have been reported by different researchers. For example, Romero et al. (2001) isolated 2 different Alternaria spp. including $A$. alternata and $A$. helianthin and one Fusarium sp. from the leaves of $P$. hysterophorus. Another endophytic fungus isolated from the roots of $P$. hysterophorus was identified as Curvularia geniculate (Priyadharsini and Muthukumar 2017). Drechslera spp. were reported for the first time in the present study as the root endophytic fungi of $P$. hysterophorus.

\section{Effect of cultural filtrate on germination and growth of weed species}

All the 3 fungi significantly affected the germination as well as the growth parameters of C. album. Alternaria spp. and Drechslera spp. reduced the rate of germination to 57 and 75\%, respectively, than the control (Table 2). Shoot and root length was also significantly reduced with the cultural filtrates of all 3 fungi. The highest shoot and root lengths were recorded for Alternaria spp. with 78 to
$82 \%$ decrease than the control. A reduction of $71 \%$ in plant biomass was recorded for Alternaria spp. Moreover, Alternaria spp. and Drechslera spp. reduced the germination of $A$. fatua by 44 and $31 \%$, respectively (Table 2). The highest inhibition of shoot and root length was noted for Alternaria spp. 60\%, followed by 38\%, respectively, which resulted in $62 \%$ less plant biomass. Although there was non-significant difference between the germination rate of Aspergillus spp. and control, plant biomass was significantly reduced (26\%) by cultural filtrate of Aspergillus spp. Similarly, the fungal cultural filtrates were also evaluated on the different growth parameters of $C$. arvensis. The cultural filtrate of Alternaria spp. was most effective in inhibiting (70\%) germination, followed by Drechslera spp. (51 \%) and Aspergillus spp. (25\%). Shoot and root length was also inhibited by the cultural filtrated of all 3 fungi. Alternaria spp. showed the highest inhibition of shoot and root length 36 and 59\%, respectively, which resulted in a $63 \%$ reduction of plant biomass (Table 2).

The results of fungal cultural filtrates against the germination and growth of weeds are in line with several 
Table 2 Effect of cultural filtrates of endophytic fungi from Parthenium hysterophorus on the germination and growth parameters of weed species

\begin{tabular}{|c|c|c|c|c|}
\hline & Germination (\%) & Shoot length (mm) & Root length (mm) & Plant biomass (mg) \\
\hline \multicolumn{5}{|l|}{ C. album } \\
\hline Control & $100.00 \pm 0.00^{\mathrm{a}}$ & $17.23 \pm 0.70^{\mathrm{a}}$ & $11.18 \pm 0.32^{a}$ & $2.02 \pm 0.17^{\mathrm{a}}$ \\
\hline Aspergillus spp. & $84.44 \pm 2.08^{b}$ & $13.10 \pm 0.26^{b}$ & $8.77 \pm 0.31^{b}$ & $1.21 \pm 0.02^{b}$ \\
\hline Alternaria spp. & $57.78 \pm 1.89^{d}$ & $3.63 \pm 0.31^{d}$ & $2.00 \pm 0.10^{d}$ & $0.59 \pm 0.06^{d}$ \\
\hline Drechslera spp. & $75.56 \pm 2.78^{c}$ & $7.33 \pm 0.45^{c}$ & $5.53 \pm 0.40^{c}$ & $0.85 \pm 0.05^{c}$ \\
\hline \multicolumn{5}{|l|}{ A. fatua } \\
\hline Control & $100.00 \pm 0.00^{\mathrm{a}}$ & $97.00 \pm 2.00^{a}$ & $120.33 \pm 1.53^{\mathrm{a}}$ & $103 \pm 1.15^{\mathrm{a}}$ \\
\hline Aspergillus spp. & $93.33 \pm 2.14^{\mathrm{a}}$ & $80.00 \pm 1.00^{b}$ & $95.67 \pm 0.58^{b}$ & $76 \pm 2.00^{b}$ \\
\hline Alternaria spp. & $55.56 \pm 1.03^{c}$ & $38.00 \pm 2.65^{d}$ & $28.67 \pm 1.53^{d}$ & $38.5 \pm 0.87^{c}$ \\
\hline Drechslera spp. & $68.89 \pm 1.10^{b}$ & $59.67 \pm 1.50^{c}$ & $73.67 \pm 2.36^{c}$ & $72.23 \pm 0.51^{b}$ \\
\hline \multicolumn{5}{|l|}{ C. arvensis } \\
\hline Control & $100.00 \pm 0.00^{a}$ & $33.33 \pm 1.53^{\mathrm{a}}$ & $51.67 \pm 1.15^{\mathrm{a}}$ & $15.30 \pm 0.75^{a}$ \\
\hline Aspergillus spp. & $75.56 \pm 3.51^{b}$ & $24.67 \pm 1.53^{b}$ & $43.67 \pm 1.53^{b}$ & $10.17 \pm 0.38^{b}$ \\
\hline Alternaria spp. & $37.78 \pm 2.85^{d}$ & $10.00 \pm 1.00^{c}$ & $18.93 \pm 0.40^{c}$ & $6.13 \pm 0.50^{c}$ \\
\hline Drechslera spp. & $48.89 \pm 2.17^{c}$ & $22.67 \pm 0.57^{b}$ & $39.67 \pm 1.52^{b}$ & $9.40 \pm 1.11^{b}$ \\
\hline
\end{tabular}

Values are mean \pm SD. Means followed by different superscripts in a row for each weed species are significantly different using LSD at $p<0.05$

already reported results. Tunali et al. (2009) demonstrated the use of different fungal species for the effective biocontrol of C. arvensis. In another study, a significant reduction in the growth parameters and germination of C. album and A. fatua sprayed with cultural filtrate of Drechslera spp. was reported (Akbar and Javaid 2012). The herbicidal effect of fungal filtrates is mainly because of the phytotoxins produced by these fungi. Many fungal phytotoxins have been isolated from endophytic and plant pathogenic fungi, which are effective in the control of specific weed. Cimmino et al. (2015a) reported a host-specific phytotoxic compound chenopodolans from a plant pathogenic fungi Phoma chenopodiicola for effective control of C. album. Cultural filtrates of Trichoderma spp. also significantly negatively affected the growth of A. fatua (Javaid and Ali 2011). Cultural filtrate of Drechslera spp. possesses some bioactive compounds, which are involved in the inhibition of growth and germination of $C$. arvensis and A. fatua (Akbar and Javaid 2012).

\section{Foliar spray pot experiment}

Fungal cultural filtrate of Aspergillus spp. and Drechslera spp. had non-significant effect on shoot length and plant biomass of C. album, whereas Alternaria spp. significantly reduced the shoot length. However, non-significant effect was observed on both shoot length and plant biomass by 19 and 44\%, respectively (Table 3). None of the fungi showed a significant effect on the shoot length of $A$. fatua;

Table 3 Effect of cultural filtrates of endophytic fungi on the growth parameters of weed species in a pot experiment

\begin{tabular}{llll}
\hline Treatments & Weed species & & \\
\cline { 2 - 4 } & Chenopodium album & Avena fatua & Convolvulus arvensis \\
\hline Shoot length (cm) & $12.04 \pm 0.28^{\mathrm{a}}$ & $21.36 \pm 0.06^{\mathrm{a}}$ & $4.02 \pm 0.10^{\mathrm{a}}$ \\
$\quad$ Control & $11.28 \pm 0.93^{\mathrm{a}}$ & $19.73 \pm 0.44^{\mathrm{b}}$ & $3.12 \pm 0.22^{\mathrm{b}}$ \\
Aspergillus spp. & $9.68 \pm 0.40^{\mathrm{b}}$ & $18.86 \pm 1.15^{\mathrm{b}}$ & $2.13 \pm 0.21^{\mathrm{c}}$ \\
Alternaria spp. & $11.60 \pm 0.45^{\mathrm{a}}$ & $19.58 \pm 0.61^{\mathrm{b}}$ & $3.33 \pm 0.25^{\mathrm{b}}$ \\
Drechslera spp. & & & $0.57 \pm 0.05^{\mathrm{a}}$ \\
Shoot biomass (g) & $0.14 \pm 0.05^{\mathrm{a}}$ & $0.31 \pm 0.05^{\mathrm{a}}$ & $0.47 \pm 0.04^{\mathrm{b}}$ \\
Control & $0.10 \pm 0.02^{\mathrm{ab}}$ & $0.29 \pm 0.03^{\mathrm{a}}$ & $0.25 \pm 0.03^{\mathrm{b}}$ \\
Aspergillus spp. & $0.08 \pm 0.01^{\mathrm{b}}$ & $0.16 \pm 0.02^{\mathrm{c}}$ & $0.32 \pm 0.05^{\mathrm{c}}$ \\
Alternaria spp. & $0.10 \pm 0.10^{\mathrm{ab}}$ & $0.23 \pm 0.03^{\mathrm{b}}$ & \\
Drechslera spp. &
\end{tabular}

Values are mean \pm SD. Means followed by different superscripts in a row for each weed species are significantly different using LSD at $p<0.05$ 
however, filtrates of Alternaria spp. and Drechslera spp. significantly reduced the shoot biomass by 46 and 23\%, respectively (Table 3). Alternaria spp. inhibited the shoot growth by $46 \%$ and shoot biomass by $55 \%$ in C. arvensis (Table 3). Obtained results are consistent with those reported by Akbar and Javaid (2012), in which a significant inhibition in the growth of C. album, A. fatua, and $P$. hysterophorus was reported when sprayed with the cultural broth of Drechslera hawaiiensis and Alternaria spp. Overall, $D$. hawaiiensis reduced the $A$. fatua germination by $54 \%$ than the control. In another study, foliar spray of cultural filtrate of Alternaria spp. reduced the P. hysterophorus growth by $16 \%$ and the plant biomass by $50 \%$ in the first week of spray (Javaid and Adrees 2009). As already described above, the negative effect on the growth of weed plants is due to the various phytotoxins produced by endophytic fungi. Mechanisms of action of known fungal phytotoxins are rarely identified. However, evidence suggests that in many cases, the modes of action of these phytotoxins do not overlap those of synthetic herbicides (Dayan et al. 2012), therefore having a great structural diversity and exclusive mechanism of action, which make screening of fungal toxins highly attractive for new herbicidal compounds (Zhang et al. 2011).

\section{Effect of cultural filtrate on REL, cellular respiration, and chlorophyll content}

A significant increase was observed in REL in the leaves of weed species sprayed with fungal cultural filtrate, except for Aspergillus spp. filtrate on A. fatua. The highest REL in weeds plants was observed in weed species treated with cultural filtrate of Alternaria spp. (52-75\%), followed by Drechslera spp. (48-63\%) and Aspergillus spp. (30-42\%) (Fig. 2). A significant reduction in cellular respiration was also observed in weed plants sprayed with the fungal cultural filtrate (Fig. 3). Alternaria spp. decreased the cellular respiration of C. album by $75 \%$, followed by Drechslera spp., 62\%, and Aspergillus spp., $51 \%$. Similarly, Drechslera spp. showed a maximum inhibition of cellular respiration in A. fatua, 51\%, followed by Alternaria spp. and Aspergillus spp., 26-18\%, respectively. Non-significant difference was observed between the effect of Alternaria spp. and Drechslera spp. on $C$. arvensis. Parallel to cellular respiration and REL, all 3 fungal species significantly reduced the chlorophyll contents of the selected weed plants (Fig. 4). Aspergillus spp. and Drechslera spp. showed similar results and reduced the chlorophyll content of C. album to $30 \mu \mathrm{g} / \mathrm{cm}^{2}$ than the control $58 \mu \mathrm{g} / \mathrm{cm}^{2}$. The highest inhibition of chlorophyll contents was shown by the filtrate of Alternaria spp. against C. album, A. fatua, and C. arvensis 61, 69, and $74 \%$, respectively.

Fungal cultural filtrates contain compounds that compromised the cell membrane integrity and increase in its permeability resulting in solute leakage and high REL. Other biochemical and physiological processes were also affected, linked to the proper functioning of the cell membrane. Cimmino et al. (2015b) reported non-proteic toxic amino acid from the cultural filtrate of Ascochyta caulina causing cell damage and necrosis in C. album leaves resulting in electrolyte leakage. In a similar study, AAL toxins isolated from A. alternata were tested against 86 different crops and weed species and reported cell damage resulting in electrolyte leakage and chlorosis

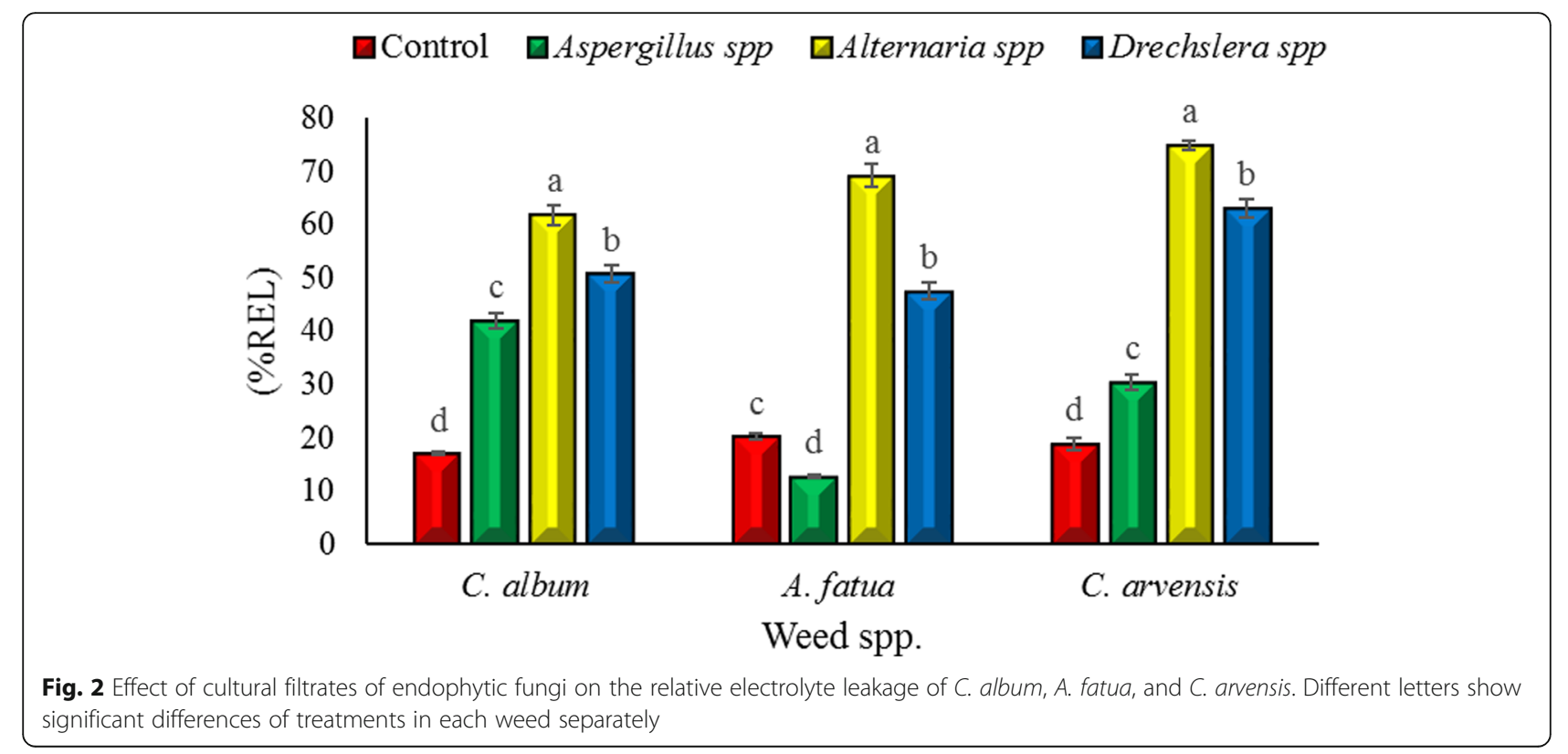




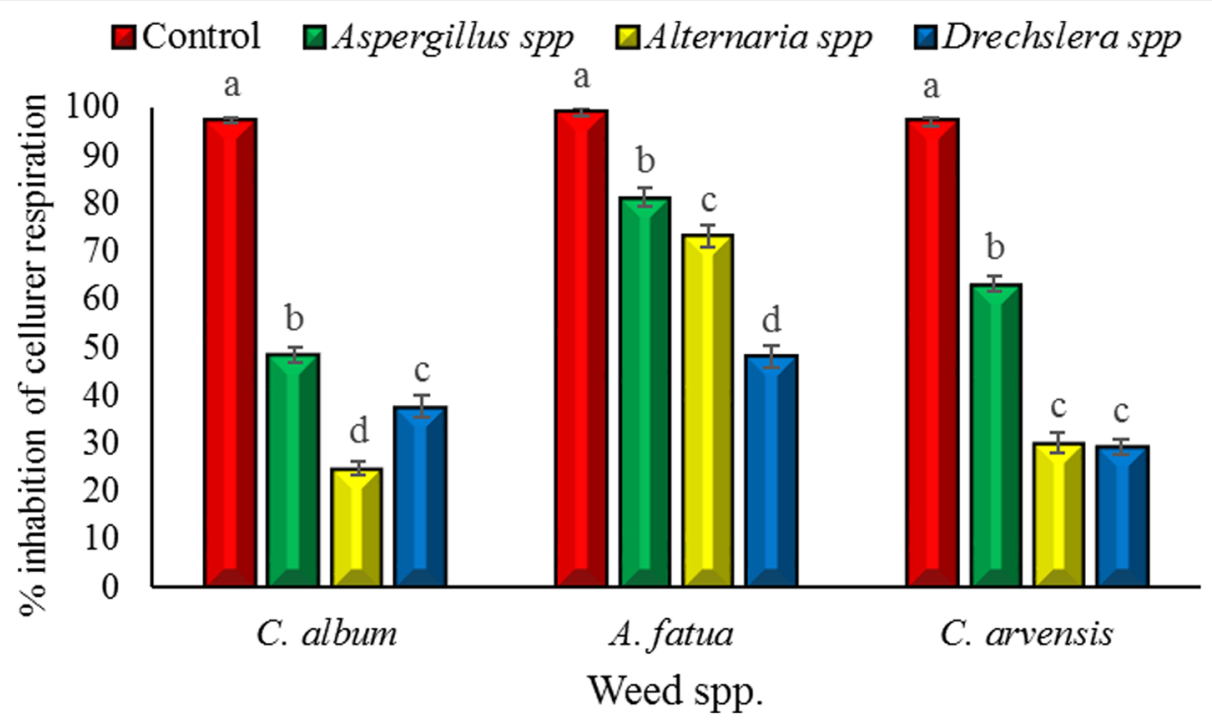

Fig. 3 Effect of cultural filtrates of endophytic fungi on the cellular respiration of C. album, A. fatua, and C. arvensis. Different letters show significant differences of treatments in each weed separately

(Abbas et al. 1995). Phytotoxic compounds like Holadysenterine and Drechslerol-C isolated from the cultural filtrate of Drechslera spp. have showed decrease in chlorophyll content and cell damage resulting in necrosis and chlorosis (Evidente et al. 2006; Akbar and Javaid 2012). A cyclic tetrapeptide isolated from Alternaria spp. inhabited chlorophyll content causing chlorosis and necrosis; these compounds compromised plasma membrane integrity and interfere with plant metabolic processes by producing reactive oxygen species (ROS) ultimately causing cell death (Abbas et al. 1995; Opara and Eno 2016).

\section{Conclusions}

The cultural filtrates of endophytic fungi of $P$. hysterophorus root exhibited strong phytotoxic effects on all three selected weeds. Among the three endophytic fungi, Alternaria spp. showed the strongest phytotoxic effect, followed by Drechslera spp. and Aspergillus spp. Cultural filtrates of all 3 fungi caused significant reduction in the germination and growth parameters of weed plants. More research is required to explore the potential of active phytotoxic compounds from other plant species and utilize them as biopesticides against the fast-spreading and aggressive weeds.

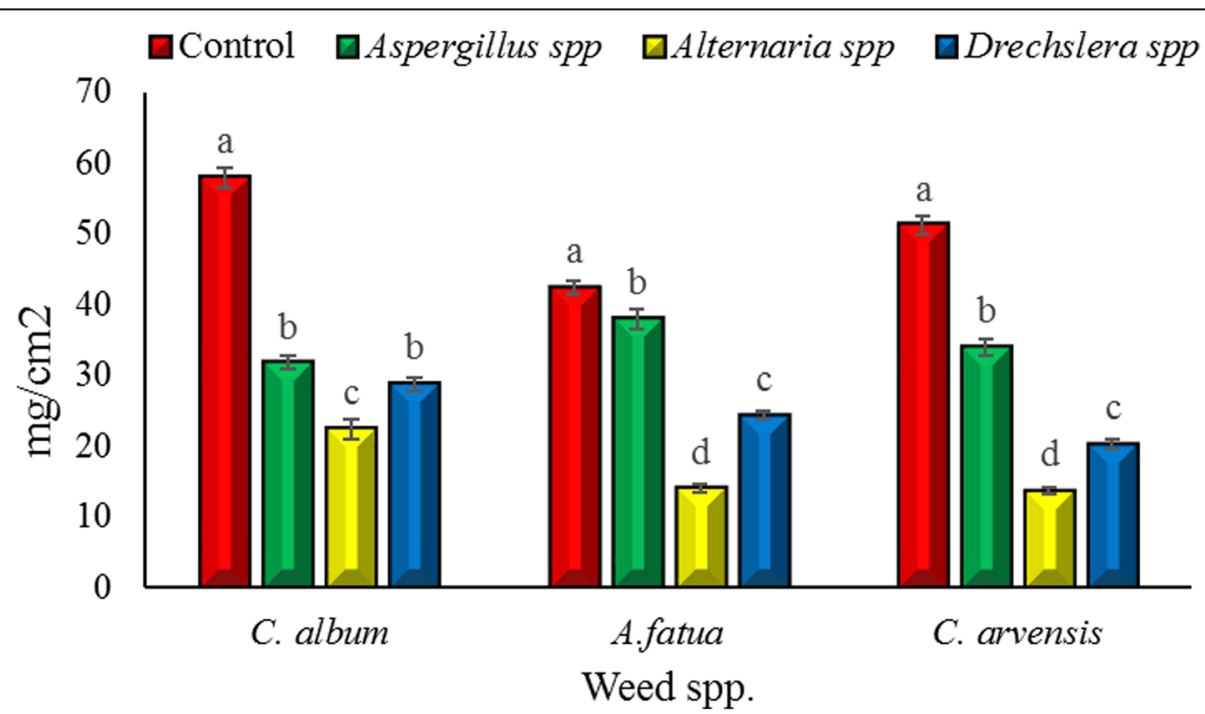

Fig. 4 Effect of cultural filtrates of endophytic fungi on the chlorophyll $\left(\mathrm{mg} / \mathrm{cm}^{2}\right)$ of C. album, A. fatua, and C. arvensis. Different letters show significant differences of treatments in each weed separately 


\section{Abbreviations}

SDA: Sabouraud dextrose agar; PDB: Potato dextrose broth; CRD: Completely randomized design; TTC: 2,3,5-Triphenyl tetrazolium chloride; EC: Electrical conductivity; LSD: Least significant difference; REL: Relative electrolyte leakage

\section{Acknowledgements}

Not applicable

\section{Authors' contributions}

MNA and AZ conceived and designed the experiments. YA performed the experiments. YA and MR collected and analyzed the data. SSA and RAAK critically revised the manuscript for intellectual content. YA and SSA wrote the paper. All authors read and approved the final manuscript.

\section{Funding}

Not applicable

\section{Availability of data and materials}

The data and materials of this study have been presented in the manuscript.

\section{Ethics approval and consent to participate}

Not applicable

\section{Consent for publication}

Not applicable

\section{Competing interests}

The authors declare that they have no competing interests.

\section{Author details}

${ }^{1}$ Department of Agricultural Chemistry, The University of Agriculture Peshawar, Peshawar, Pakistan. ${ }^{2}$ Department of Plant Pathology, The University of Agriculture Peshawar, Peshawar, Pakistan. ${ }^{3}$ Institute of Vegetables and Flowers, Chinese Academy of Agricultural Sciences, Beijing, People's Republic of China. ${ }^{4}$ Department of Environmental Science and Engineering, Govt. College University, Faisalabad, Pakistan.

Received: 3 September 2020 Accepted: 6 November 2020

\section{Published online: 19 November 2020}

\section{References}

Abbas HK, Tanaka T, Duke SO, Boyette CD (1995) Susceptibility of various crop and weed species to AAL-toxin, a natural herbicide. Weed Technol 125-130. https://www.jstor.org/stable/3987833?seq=1

Akbar M, Javaid A (2012) Herbicidal activity of fungal culture filtrates against Chenopodium album L. and Avena fatua L. J Animal Plant Sci 22:977-982 http://www.thejaps.org.pk/docs/N-22-4/26.pdf

Alshallash KS (2018) Germination of weed species (Avena fatua, Bromus catharticus, Chenopodium album and Phalaris minor) with implications for their dispersal and control. Ann Agric Sci 63(1): 91-97. https://doi.org/10. 1016/j.aoas.2018.05.003

Cimmino A, Masi M, Evidente M, Evidente A (2015a) Fungal phytotoxins with potential herbicidal activity to control Chenopodium album. Nat Prod Comm 10(6). https://doi.org/10.1177/1934578X1501000677

Cimmino A, Masi M, Evidente M, Superchi S, Evidente A (2015b) Fungal phytotoxins with potential herbicidal activity: chemical and biological characterization. Nat Prod Rep 32(12): 1629-1653. https://doi.org/10.1039/ C5NP00081E

Dayan FE, Owens DK, Duke SO (2012) Rationale for a natural products approach to herbicide discovery. Pest Manag Sci 68: 519-528. https://doi.org/10.1002/ ps.2332

Evidente A, Andolfi A, Cimmino A, Vurro M, Fracchiolla M, Charudattan R, Motta A (2006) Ophiobolin E and 8-epi-ophiobolin J produced by Drechslera gigantea, a potential mycoherbicide of weedy grasses. Phytochem 67(20): 2281-2287. https://doi.org/10.1016/j.phytochem.2006.07.016

Gilman J (2001) A manual of soil fungi, 2nd Indian edition. Biotech Books, Delhi York, NY: John Wiley \& Sons, Inc 17: 336-341. https://doi.org/10.3389/fpls. 2015.00659

Hamzah TNT, Lee SY, Hidayat A, Terhem R, Faridah-Hanum I, Mohamed R (2018) Diversity and characterization of endophytic fungi isolated from the tropica mangrove species, Rhizophora mucronata, and identification of potential antagonists against the soil-borne fungus, Fusarium solani. Front Microbiol 9: 1707. https://doi.org/10.3389/fmicb.2018.01707

Harding DP, Raizada MN (2015) Controlling weeds with fungi, bacteria and viruses: a review. Front Plant Sci 6:659

Javaid A, Adrees H (2009) Parthenium management by cultural filtrates of phytopathogenic fungi. Nat Prod Res 23: 1541-1551. https://doi.org/10.1080/ 14786410902726167

Javaid A, Ali S (2011) Alternative management of a problematic weed of wheat Avena fatua L. by metabolites of Trichoderma. Chi J Agri Res 71:-205

Kanchiswamy CN, Malnoy M, Maffei ME (2015). Bioprospecting bacterial and fungal volatiles for sustainable agriculture. Tre PI Sci 20(4): 206-211. https:// doi.org/10.1016/j.tplants.2015.01.004

Kaur S, Singh HP, Mittal S, Batish DR, Kohli RK (2010) Phytotoxic effects of volatile oil from Artemisia scoparia against weeds and its possible use as a bioherbicide. Ind Crops Prod 32(1): 54-61. https://doi.org/10.1016/j.indcrop. 2010.03.007

Khan RAA, Najeeb S, Mao Z, Ling J, Yang Y, Li Y, Xie B (2020b) Bioactive secondary metabolites from Trichoderma spp. against phytopathogenic bacteria and Root-Knot nematode. Microorganisms. 8: 401. https://doi.org/10. 3390/microorganisms8030401

Khan RAA, Najeeb S, Xie B, Li Y (2020a) Bioactive secondary metabolites from Trichoderma spp. against phytopathogenic fungi. Microorganisms. 8: 817 . https://doi.org/10.3390/microorganisms8060817

Korres NE (2018) Agronomic weed control: a trustworthy approach for sustainable weed management. Non-Chem Weed Control, Elsevier: 97-114 https://doi.org/10.1016/B978-0-12-809881-3.00006-1

Melander B, Matt L, Adam SD, Eric RG, Paolo B, Anna-Camilla M, Jesper R, Rommie W, Francesco V (2017) Non-chemical weed management. In Weed Research, pp. 245-270. Wiley, 2017

Novichonok EV, Novichonok AO, Kurbatova JA, Markovskaya EF (2016) Use of the atLEAF+ chlorophyll meter for a nondestructive estimate of chlorophyll content. Photosynthetica 54(1): 130-137. https://doi.org/10.1007/s11099-0150172-8

Opara EU, Eno IP (2016) Overview on toxins as weapons used by pathogens to invade plants tissues. Int J Agri Earth Sci 2(5):1-11

Picman J, Picman AK (1984) Autotoxicity in Parthenium hysterophorus and its possible role in control of germination. Biochem System Ecol 12:287-292. https://doi.org/10.1016/0305-1978(84)90051-6

Priyadharsini P, Muthukumar T (2017) The root endophytic fungus Curvularia geniculata from Parthenium hysterophorus roots improves plant growth through phosphate solubilization and phytohormone production. Fungal Ecol 27: 69-77. https://doi.org/10.1016/j.funeco.2017.02.007

Rashid MI, Mujawar LH, Shahzad T, Almeelbi T, Ismail IM, Oves M (2016) Bacteria and fungi can contribute to nutrients bioavailability and aggregate formation in degraded soils. Microb Res. 183: 26-41. https://doi.org/10.1016/j.micres. 2015.11.007

Romero A (2001) Fungal latent pathogens and endophytes from leaves of Parthenium hysterophorus (Asteraceae). Fungal Div 7:81-87 http://www fungaldiversity.org/fdp/sfdp/FD_7_81-87.pdf

Tunali B, Kansu B, Berner DK (2009) Biological control studies on Convolvulus arvensis L. with fungal pathogens. J Turk Phytopathol 38:1-8 https://www.ars. usda.gov/research/publications/publication/?segNo115=265287

Yadav IC, Devi NL (2017) Pesticides classification and its impact on human and environment. Env Sci Eng 6:140-158

Zhang JP, Duan GF, Zhou YJ, Yu LQ (2011) Fungal phytotoxins for weed management. Allel J 27:1-13

Zimdahl RL (2018) Fundamentals of weed science, Academic press. Imprint of Elsevier. 125, London Wall EC2Y, 5AS, UK

\section{Publisher's Note}

Springer Nature remains neutral with regard to jurisdictional claims in published maps and institutional affiliations. 